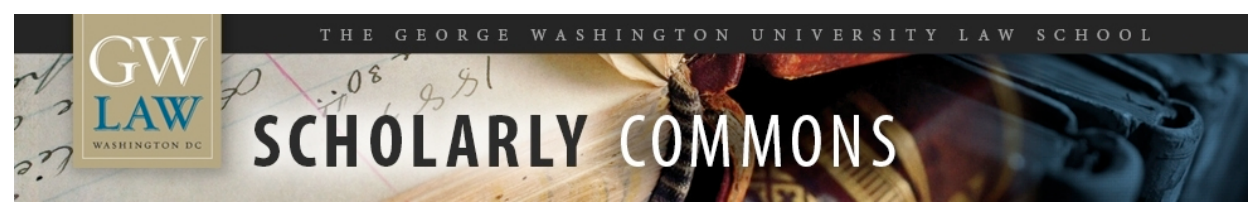

\title{
Tale of Three Regulatory Regimes - Dynamic, Distracted and Dysfunctional: Sweden, the United Kingdom and the United States
}

Christopher R. Yukins

George Washington University Law School, cyukins@law.gwu.edu

Andrea Sundstrand

Stockholm University

Michael Bowsher QC

King's College London

Follow this and additional works at: https://scholarship.law.gwu.edu/faculty_publications

Part of the Law Commons

\section{Recommended Citation}

Yukins, Christopher R., Tale of Three Regulatory Regimes -- Dynamic, Distracted and Dysfunctional: Sweden, the United Kingdom and the United States (2018). 2017 Gov. Contr. Yr. Rev. Conf. Br. Int'I 2-1 (2018); GWU Law School Public Law Research Paper No. 2018-08; GWU Legal Studies Research Paper No. 2018-08. Available at SSRN: https://ssrn.com/abstract=3135805

This Article is brought to you for free and open access by the Faculty Scholarship at Scholarly Commons. It has been accepted for inclusion in GW Law Faculty Publications \& Other Works by an authorized administrator of Scholarly Commons. For more information, please contact spagel@law.gwu.edu. 
Reprinted from West Government Contracts Year In Review covering 2017 Conference Briefs, with permission of Thomson Reuters. Copyright ( 2 2018. Further use without the permission of West is prohibited. For further information about this publication, please visit west.thomson.com/store, or call 800.328.9352.

\title{
INTERNATIONAL PROCUREMENT DEVELOPMENTS IN 2017-PART I: A TALE OF THREE REGULATORY REGIMES-DYNAMIC, DISTRACTED AND DYSFUNCTIONAL: SWEDEN, THE UNITED KINGDOM AND THE UNITED STATES
}

\author{
Andrea Sundstrand \\ Associate Professor \\ Stockholm University \\ Michael Bowsher QC \\ Monckton Chambers \\ Visiting Professor, King's College, London \\ Christopher Yukins \\ Professor of Government Procurement Law \\ George Washington University Law School, Washington, D.C.
}

\section{INTRODUCTION}

It was the best of times, it was the worst of times -- a year marked by genuine progress in public procurement law in some nations, and partial paralysis in others. This article presents the experience of Sweden (as part of the European Union), the United Kingdom (which is slated soon to depart from the EU, via "Brexit"), and the United States (in the first year of the Trump administration). As the discussion below reflects, while Sweden and other members of the European Union continue to develop a vital and evolving body of public procurement law, the United Kingdom has been distracted by Brexit, and the United States made, in 2017, almost no regulatory progress at all -- though stasis itself yielded some interesting insights.

This piece proceeds in three parts, prepared primarily by Andrea Sundstrand (Part II, on Sweden and the European Union), Michael Bowsher (Part III, on the United Kingdom) and Christopher Yukins (Introduction, Part IV on the United States, and Conclusion).

\section{EXPERIENCE IN SWEDEN AS A EUROPEAN MEMBER STATE ${ }^{1}$}

In 2017, Sweden implemented the European Union's public procurement Directives which were adopted in 2014. See, e.g., Andrea Sundstrand, International Procurement Developments in 2016 -- Part III: The European Union's New Procurement Rules, 2017 Gov't Contracts Year in Review Briefs 5. Sweden's implementation reflected longstanding national concerns for protecting labor conditions in public procurement.

\section{A. Labor conditions in public procurements in Sweden}

On January 1, 1994, Sweden enacted its first law on public procurement based on EU Directives. After the act came into force and for a long period of time, the general perception in Sweden, as well as in the EU Commission, was that it was only possible in public procurements to set selection criteria that referred to a financial advantage for the contracting authority (see, for example, Swedish preparatory work 1992/93: 88, p. 52 and the Commission's Interpretative Communication on the Public Procurement Opportunities, COM (2001) 274 final). This made it less likely that labor conditions would be considered as selection criteria in awarding public contracts.

Not even the decision of the European Court of Justice (ECJ), which in its 1988 judgment in Beentjes (C-31/87, EU:C:1988:422) allowed for consideration of labor conditions, convinced attorneys and contracting authorities to consider such criteria possible. Instead it was generally assumed that it was only possible

$$
\text { Int'l-2-1 }
$$


in public procurements to have criteria that could somehow be measured economically. In the judgment in Beentjes, the ECJ ruled that it was possible in a public procurement to require employment of long-term unemployed in the performance of a contract, provided that the requirement did not violate general principles of EU law, especially the principle of non-discrimination.

The evolution in approach that has been underway since January 1994 has been slow, but Sweden was long on the way to making it easier to impose labor conditions and criteria in public procurements. The next step on that path was the Amsterdam Treaty that came into force in 1999 and brought about changes in the EU, which included the promotion of a high level of employment and gender equality in the European Union. The Treaty of Lisbon entered into force ten years later, in 2009, giving rise to the so-called "Lisbon Strategy." It stated that the employment rate in the EU would be at least 70 percent by 2010 .

Regarding procurement rules, the Commission published a number of guidances on social procurement in the early 2000s. One of them was the Commission's guide Buying Social: A Guide to Taking Account of Social Considerations in Public Procurement (2010), http://ec.europa.eu/social/BlobServlet?docId=6457\& langId=en. The guide states that the promotion of workers' rights in accordance with International Labor Organisation (ILO) conventions can be considered as a means of bringing social considerations into public procurements. Id. at 8; see, e.g., Henrik Karl Nielsen, Labour Clauses in Public Contracts: ILO Convention No. 94 in the European Union after RegioPost, 2017 Pub. Proc. L. Rev 201. Several judgments from the ECJ, including Concordia (17 September 2002, C-513/99, EU:C:2002:495), have also paved the way for increased opportunities to have labor conditions in public procurements. In 2017, the Swedish Parliament even adopted a legal provision in the Swedish Procurement Act which required that specific labor conditions be considered in certain public procurements.

\title{
B. The EU Procurement Rules
}

\section{New EU provisions on labor conditions}

The European Procurement Directive 2014/24 was adopted in the Spring of 2014, and with it the EU Commission and the Member States took another step forward in terms of labor conditions in public procurements. See, e.g., Abby Semple, Socially Responsible Public Procurement (SRPP) Under EU Law and International Agreements the GPA, CETA and the EU-Ukraine Deep and Comprehensive Free Trade Area, 12 Eur. Proc. \& Pub Priv. Part L. Rev. 293 (2017). Article 18.2 of the Directive states:

\begin{abstract}
Member States shall take appropriate measures to ensure that in the performance of public contracts economic operators comply with applicable obligations in the fields of environmental, social and labour law established by Union law, national law, collective agreements or by the international environmental, social and labour law provisions listed in Annex X.
\end{abstract}

In Sweden, some trade unions argued that this article should be interpreted as making it possible in public procurements to require that suppliers awarded public contracts have collective agreements. However, after two investigations, the Swedish Competition Authority announced that it was unlikely to be possible to impose collective agreements on suppliers in public procurements, as it would probably be contrary to the principles of equal treatment and proportionality (see, among other things, Commission Research Report 2015: 2). On the other hand, the investigations revealed that

$$
\text { Int'l-2-2 }
$$


it was probably possible to impose labor conditions in public procurements per $s e$, provided that the conditions were compatible with Union law.

\section{The Posted Workers Directive 96/71/EC}

One important aspect of the debate regarding labor conditions was the Posted Workers Directive 96/71/EC, which in most cases prevented contracting authorities from imposing requirements beyond the scope of the so-called hard core work conditions. See European Commission, "Posted Workers," http://ec.europa.eu/social/main.jsp?catId=471.

The Posted Workers Directive 96/71/EC is an EU directive concerned with the free movement of workers within the European Union. The directive applies when a company agrees to provide a service to a client in another Member State and needs to send staff there in order to carry out this work, when a worker is posted in another country through arrangements within a group of companies, with the parent and subsidiaries based in different member states, and when a worker is posted through an agreement between an employer and an employment agency. See Directive 96/71/EC of the European Parliament and of the Council of 16 December 1996 concerning the posting of workers in the framework of the provision of services, http://eur-lex. europa.eu/legal-content/EN/ALL/?uri=CELEX:31996L0071; Clemens Kaupa, Public Procurement, Social Policy and Minimum Wage Regulation for Posted Workers: Towards a More Balanced

Socio-Economic Integration Process?, European Papers, Vol. 1, 2016, No. 1, European Forum, Insight of 16 April 2016, pp. 127-138, http://www. europeanpapers.eu/en/system/files/pdf version/EP eJ 2016111 Insight Clemens_Kaupa.pdf.

The hard core conditions -- which contracting agencies may address in their requirements -- include those relating to working hours, holidays, minimum wages, conditions for making workers available, safety, health and hygiene at the workplace, protection measures with regard to working and employment conditions for pregnant women and women who have recently given birth, as well as children and young people, and conditions regarding non-discriminatory treatment. Requirements covering other employment conditions, such as pensions and insurance, do not however fall within the "hard core" and so may not be conditions imposed by contracting public agencies. See generally Adrian Brown, The Lawfulness of a Regional Law Requiring Tenderers for a Public Contract to Undertake to Pay Workers Performing that Contract the Minimum Wage Laid Down in the Law: Case C-115/14 RegioPost, 2016 Pub. Proc. L. Rev. NA49.

The Posted Workers Directive 96/71/EC applies only if there is a so-called "definite cross-border interest." In procurement situations, this occurs when tenderers from a Member State are interested in and/or participate in and submit tenders in a public procurement in another Member State. If it is a purely internal procurement in one Member State, such as in Sweden, then European Union law is not applicable, nor is the Posted Workers Directive 96/71/EC. In such cases, a contracting authority could possibly include labor conditions in line with Swedish collective agreements that go beyond the "hard core," which is generally not possible if European Union law applies.

\section{The Two Bills from the Swedish Government}

Prior to the new Swedish Procurement Act, which entered into force on 1 January 2017, the Swedish Government decided to set up a committee to

Int'l-2-3 
review the possibilities of imposing labor conditions in public procurement (SOU 2015: 78). The committee presented its partial report on September 1,2015 , suggesting it would be mandatory for contracting authorities to impose labor conditions regarding pay, vacation and working hours in public procurements. The committee also suggested that contracting authorities themselves could decide on further labor conditions, such as conditions regarding other leave than vacation and conditions on insurances, pensions and on other terms of employment.

The committee also wanted it to be possible for contracting authorities to impose more extensive labor conditions on Swedish suppliers than on suppliers from other Member States using foreign labor forces. The committee thought that the possibility of setting conditions for suppliers performing work in a procurement through posted work was limited by the Posted Workers Directive 96/71/EC (discussed above). Therefore, those foreign suppliers would be subject only to labor conditions covered by the "hard core" defined by the Directive, such as salary, working hours and holidays. The conclusions of the committee were fiercely criticized, as several experts said it was not possible to impose different terms on domestic and foreign suppliers in public procurements (this is an issue that is still unresolved today, but where the Swedish Supreme Administrative Court (HFD) has issued a permit to review, see case no 4092-17).

The government ultimately chose to submit a bill in the Autumn of 2016, actually Sweden's most comprehensive legislative proposal ever, under which conditions for requirements other than those in the "hard core" were included (prop. 2015/16:195). The Swedish Parliament chose to reject that part of the bill, however. The Swedish Act on Public Procurement (LOU) entered into force on 1 January 2017 with the four proposed but rejected paragraphs, but they were empty of content. Instead, the Swedish government prepared a new bill (prop. 2016/17:163) with four new paragraphs on labor conditions, and these were finally accepted by the Swedish Parliament in the Spring of 2017. The four paragraphs came into force on 1 June 2017 and paragraphs 2-5 to of chapter 17 of the LOU are now filled with content. An English-language translation of the Swedish Act on Public Procurement, published by the Swedish Competition Authority, is available at http:// www.konkurrensverket.se/globalassets/english/publications-and-decisions/ swedish-public-procurement-act.pdf.

\section{The New Swedish Labor Provisions}

The new provisions on labor conditions are found, as noted, in chapter 17 of the Swedish Act on Public Procurement. Initially, it is stated that labor conditions constitute so-called conditions of performance. These are conditions which a supplier must agree to and which are to be fulfilled during the performance of the contract, such a hiring long-term unemployed persons. These requirements are therefore not evaluated and scored. In summary, the new provisions imply that labor law conditions relating to pay, working hours and holiday are to be made in public procurement if an award is to be at or above a current EU monetary threshold, does not concern a procurement of social services or other special services, and if the procurement has commenced on or after June 1, 2017. However, the provisions are applicable only if they are "necessary" and if it is at all possible to determine the labor conditions.

If we look at the different criteria individually, the first criterion is that the labor conditions in public procurement are mandatory only if the procurement 
meets or exceeds the current EU monetary threshold. The EU thresholds mark the point at which the EU Procurement Directives are applicable, and thus, as a rule, so is European Union law. The EU thresholds are for government goods and services EUR 134,000, for other contracting authorities (for example, municipalities, county councils, public utilities, associations and foundations) EUR 207000 , and for all contracting authorities in procuring public works, EUR 5,186,000. All values are exclusive of VAT. It is estimated that the national public procurement below the thresholds constitutes 75 percent of all national public procurement in Sweden; this means, then, that the provisions do not apply in the majority of public procurements.

Public procurements relating to social services or other special services are exempted from the obligations for labor conditions. This means, among other things, that the provisions do not apply to certain healthcare, social services and hotel and restaurant services. The reason for these services being exempted is to simplify public procurements in these areas, especially for small businesses.

A procurement is commenced once the contracting authority has chosen a procurement procedure. If that occurred in a procurement on or after June 1,2017 , the procurement is covered by the new provisions.

Requirements regarding labor conditions should be made if necessary, but when is it necessary? According to the prepatory work (prop. 2016/17:163) for the labor conditions, the contracting authority shall make an overall assessment in the light of the risks of unfair working conditions and distortion of competition in connection with the public procurement. The contracting authority shall indicate that the assessment forms part of the determination of the subject of the contract. The Swedish National Procurement Authority indicates on its website that the term "necessary" does not contain any explanation for when something is necessary or not. There is also no established methodology or method today to make feasibility assessments. The Swedish National Procurement Authority has, however, developed proposed criteria to be used in certain industries where there is a risk of tax evasion or wage dumping.

According to the Swedish legislation, a contracting authority shall use labor conditions only if it is possible to determine what these labor conditions are. If there is no available information for setting the level of a condition, e.g., regarding wages, the contracting authority does not need to use that condition. The preparatory work for the new provisions (prop. 2016/17:163) on labor conditions in public procurement stipulates that if the levels of salaries are not stated in the applicable collective agreements because they are agreements without fixed salary levels (so-called non-negotiable agreements), if the parties to a collective agreements keep the agreed salaries secret or if the parties' interpretation of the terms is such that they cannot be used at all, the contracting authority will lack the basis for the terms. Under these circumstances, a contracting authority is not obliged to use the otherwise obligatory condition on salary. However, this does not mean that the other applicable conditions are not to be used, that is, those regarding working hours and holidays.

\section{E. Summarizing Conclusions}

The legal situation on provisions on labor conditions in public procurement in the EU is difficult and complicated. The reason is that it is not possible to 
take into consideration only national provisions and regulations. All European Union law -- including directives addressing procurement and workers posted across borders -- applies to public procurement above the applicable monetary thresholds. As a European Member State, Sweden must reconcile the sometimes conflicting demands of protecting workers, ensuring the free flow of labor across the European market, and maintaining fair and open competition for public procurement contracts.

The fact that the Swedish Government uses the procurement act to achieve policy goals regarding labor conditions does not make reconciling these demands easier. The Swedish Government claims that Sweden had to impose mandatory labor conditions to fulfill its obligations under Directive 2014/24/EU, regarding procurement. However, if you will recall the provision in Article 18.2 of the Directive, it is not only labor conditions that are cited in the article. Article 18.2 also states that Member States shall take appropriate measures to ensure that economic operators comply with the applicable environmental and social obligations laid down by Union law, national law, collective agreements or international environmental, social and labor law provisions in the performance of public contracts. It is an open question as to what compelling requirements the Swedish Government will propose, and when, to protect those other interests as well.

\section{UPDATE FROM THE UNITED KINGDOM ${ }^{2}$}

A detailed report was prepared for the Year in Review in February 2017, see Michael Bowsher, Brexit Mayhem: UK Procurement Regulation After Brexit, 2017 Gov't Contracts Year in Review Briefs 6, which attempted to project the consequences of the June 2016 Brexit referendum for public procurement in the UK. This year a great deal of effort has gone into political aspects and consequences of Brexit but little has changed that would provide any better fix as to where public procurement regulation is likely to end up in the long term.

\section{A. A Few Headline Events in 2017}

Just as in any year there was a pipeline of challenges and case law (see the summaries in the Public Procurement case law digests for 2017 at https:// uk.practicallaw.thomsonreuters.com/2-532-4362?transitionType $=$ Default\&c ontextData $=($ sc. Default $) \&$ firstPage $=$ true $\& b h c p=1)$. There was probably little in the new case law of any great interest beyond the UK procurement law community. There have however been some indications as to possible routes for development in the procurement challenge climate. A few headline cases illustrate important trends.

There have been relatively few challenges in the UK over the years concerning organizational conflict of interest ("OCIs" in the United States). A major challenge concerning management of the major new LondonScotland rail project, HS2, was one of the first such challenges and is a good example of litigation bringing results in that it has heightened the sensitivity to these issues on HS2 and other important projects. Even so, the government continued to adopt its rather unattractive application of thinly veiled threats to stifle challenges ${ }^{3}$ : for a summary of the story see http:// www.railtechnologymagazine.com/Rail-News/mace-decides-not-to-take-legalaction-against-hs2-

In a bid protest concerning tender evaluation in the nuclear industry (noted in last year's note), the government had to pay out over $£ 100$ million in damages to two bid protestors. The power of such a "terrifying" award of

$$
\text { Int'l-2-6 }
$$


damages can be seen in the increasing attention being given to improvements in bid evaluation procedures: http://www.telegraph.co.uk/business/2017/03/27/ governments-bungled-handling-nuclear-decommissioning-deal-hits/

And a cavalier approach to procurement comes back to bite a Brexiteer: https://www.economist.com/news/britain/21726360-expensive-projectbecomes-expensive-mistake-how-london-threw-46m-thames. The proposed "Garden Bridge," one of the Foreign Secretary's vanity projects from his time as Mayor of London, has become the subject of significant investigation and comment. His, at best, casual approach to procurement issues has been the subject of substantial criticism in an independent report: https://www.london. gov.uk/independent-review-garden-bridge-project. Unfortunately the legal remedies regime failed to achieve any concrete outcome. Perhaps the next steps will impose a political price: https://www.architectsjournal.co.uk/news/ boris-johnson-summoned-by-city-hall-over-garden-bridge-debacle/10026302. article.

\section{B. The Current Key Features of a Post-Brexit Landscape}

There has been growing discussion as to the shape of procurement law in a post-Brexit environment. For a flavor of the issues being discussed see http://blogs.sussex.ac.uk/uktpo/files/2016/11/Briefing-Paper-8.pdf \& http:// live.barcouncil.netxtra.net/media/574665/brexit paper 19 - public procurement.pdf, and Pedro Telles \& Albert Sanchez-Graells, Examining Brexit Through the GPA's Lens: What Next for UK Public Procurement Reform?, 47 Pub. Cont. L.J. 1 (2017).

It is rather difficult, though, to make any confident prediction as to final shape of UK procurement law. This note assumes that - as predicted in the note for Year in Review last year - the UK proceeds towards a Trainwreck Brexit in which the future UK-EU relationship is governed by a short agreement. The current driverless approach would then lead the UK to one of the following outcomes.

\section{"Norway"}

This is short hand for membership of the European Economic Area ("EEA") or for an arrangement akin to it. For a range of political reasons on both sides of the UK/EU27 relationship, this currently seems inconceivable. It would lead to the UK continuing to be a full participant in EU public procurement law while having a substantially reduced role in its direction.

\section{"Canada"}

This is short hand for an arrangement akin to the Comprehensive Economic and Trade Agreement (CETA) trade agreement now in place between Canada and the EU (which is discussed in Paul Lalonde's accompanying note in this volume). In the current political situation this is the most intense arrangement that the UK can expect to get without bringing the whole Brexit process to a halt: http://jackofkent.com/2018/01/the-subtle-rhetoric-of-barniers-now-famous-graph/. The agreement itself would provide for a very much reduced scope and intensity of public procurement law review than is provided under the EU regime. The procurement chapter of CETA is relatively limited by comparison with current EU arrangements so there must be a likelihood that the procurement component of the Canada model would be a rather more extensive than is provided for in the CETA arrangements. This will depend upon the balance of negotiating advantage in the next few months. 


\section{"GPA"}

Perhaps the most likely outcome for a public procurement perspective is that the UK continues to behave as if it were subject to the rules of the WTO Government Procurement Agreement, either because it is agreed or established that it is still a Member, or because it wishes to become a Member.

\section{A Blank Slate}

This is probably only a likely outcome in the event of a movement to a genuinely socialist government. This must be regarded as rather likely over the next 5 years. The Labour Party leadership is probably more genuinely socialist than at any time since the 1920s. There has never been a Labour government of this hue. A full-on rejection of much of the architecture of the international trade system must be a possibility in the event of such a government being elected. What did Marx have to say about public procurement? Presumably like all law it just withers away (Collins, Marxism and Law (OUP)?

\section{The Interim Situation}

It is now clear that at least until the end of a post-Brexit transition period, EU public procurement law will apply in the UK almost unaffected by Brexit. (A number of points of procurement mechanics will have to change to reflect the fact, for instance, that contract notices might no longer appear in the Official Journal of the EU.) That interim regime will presumably run on to late 2020, early 2021. Under the EU (Withdrawal) Bill the existing implementation of EU public procurement law would stay in place, and the existing decisions of the Court of Justice of the European Union would remain binding. Future decisions on the same legislation would be authoritative, at least for a time.

\section{Procurement and Trade Agreements}

The government has currently placed great confidence in its notion that a new web of post-Brexit international trade agreements will bring wealth and happiness to all. See https://www.gov.uk/government/publications/tradewhite-paper-preparing-for-our-future-uk-trade-policy-government-response/ trade-white-paper-preparing-for-our-future-uk-trade-policy-governmentresponse

The possibility of a future UK-US trade agreement is much discussed. It is hard to see much cause for optimism about this in the current climate, which has been complicated by personal politics. https://news.sky.com/story/ trump-royal-wedding-snub-could-hit-post-brexit-trade-deal-11199343. In procurement terms one might expect that, as now, the areas where the U.S. might hope to see opening up of trade would be in the health sector where the National Health Service (NHS) as a large influential purchaser remains an increasingly important purchaser of health goods and services (https://www. theguardian.com/society/2017/dec/29/richard-branson-virgin-scoops-1bnpounds-of-nhs-contracts). This is controversial enough when the commercial beneficiaries of health service contracts are UK companies. Any further opening up of contracts to non-UK entities will be politically toxic for any UK government. So in the article above the government is reported as asserting:

"Decisions about public services, for example the National Health Service, will be made by UK governments, including devolved administrations, not our trade partners. The UK's public health 
sector is protected by specific exceptions and reservations in EU trade agreements which allow it to introduce or reintroduce more trade-restrictive policy measures in future if desirable. As we leave the EU, the UK will continue to ensure that rigorous protections for the NHS are included in all trade agreements to which it is party. The UK government ensures that decisions about how public services and outcomes are delivered for UK citizens are made by UK governments, not our trade partners.”

This would appear to take at least one chip that the UK might offer off the table.

Other significant difficulties are presented by the terms of the Guidelines agreed in December 2017 by the UK and the EU27. Specifically on the issue of the relationship between Ireland and Northern Ireland it asserts that the single market in the United Kingdom will be maintained while looking for specific solutions to address the unique circumstances of the island of Ireland. It is said that:

"In the absence of agreed solutions, the United Kingdom will maintain full alignment with those rules of the Internal Market (of the EU) and the Customs Union (of the EU) which, now or in the future, support North-South cooperation, the all-island economy and the protection of the 1998 Agreement."

There seem to be no realistic "agreed solutions" on the table and in the absence of such solutions Northern Ireland must be aligned with the rules of the EU Internal Market. In order to maintain the UK Internal Market (and incidentally for the Conservative government to hold on to the Ulster votes it depends on to stay in power) it will have to apply the same rules in Great Britain and Northern Ireland. So no material departure from EU rules could be on offer - this raises broader questions about what the point of Brexit might then be. But in the context of the UK-U.S. relationship it raises real questions as to what the UK could possibly offer as a more generous offering than is currently available under current trading arrangements constrained by EU law. It also raises a paradox or contradiction in the whole situation as I have noted above that this "Norway" type situation is probably inconceivable, yet it may be the only one that is consistent with the agreed constraints on the process.

Does anyone in the audience have any thoughts as to what else the UK might offer that might be of interest to the U.S. in negotiating the procurement chapter of a trade agreement? Correspondingly, it is not immediately apparent that there is any particularly significant and realistic opportunity for the further opening up of public sector business in the U.S. to UK interests. In the current transactional approach taken to such matters, it is hard to know what incentive there might be for any arrangements to be agreed that are any broader than those provided for under GPA.

\section{E. Potential Substantive Changes to UK Procurement Law}

Last year's note for the Year in Review, supra, identified some changes that might be made to procurement law once the UK law was no longer bound by the letter of EU law. That list has been reflected in subsequent comments from various bodies, from arch-Brexiteering lobby groups to other more neutral bodies such as the Local Government Association. I focus here on a selection of these. 
- Procurement Procedures: there is a pointless profusion of procurement procedures, particularly for complex procurements, such as Public Private Partnerships. Each is unnecessarily detailed, particularly as the real difficulties usually turn not on the precise terms of the procedure but on the true meaning of the general principles of equal treatment and transparency that govern all procedures. All the specified procedures could probably be abolished and replaced with a general obligation to conduct a fair and transparent process. A more rigorous elaboration of the role of competition concerns in public procurement could also be introduced, particularly if procurement law were freed of the need to treat the EU internal market objective, see, e.g., Pedro Telles \& Albert Sanchez-Graells, supra, at 4-5, as the primary goal.

- The UK has increasingly developed procurement policies which emphasize the need for enhanced local and social value in procurement. (This parallels developments in Sweden, discussed above.) These developments have often flirted with non-compliance with the EU's still strict, internal market driven approach to these matters. Some movement to enhanced use of these measures may be expected. The government has made it clear that it expects to establish significant preferences for small business following on research into the equivalent U.S. programmes (https://www.gov.uk/government/publications/ leveraging-public-procurement-to-grow-the-innovation-economy-an-independentreview-of-the-small-business-research-initiative-sbri)

- Housing: one of the most pressing policy problems is to deliver housing (and related services) to a population which is still growing and expected to surpass that of France, and in due course Germany over the next 2 or 3 decades. The current definition of works contract has brought within the scope of the procurement regime a number of development arrangements that might meet this challenge. Amendments to the way in which procurement law applies to public sector property developments might be expected. It can also be expected that the definition of public body covered by procurement legislation could be narrowed so that third sector social housing bodies are no longer covered.

- The debarment measures are weak, unclear and impractical without more working through of the detail of their operation. Given the increasing pressure to apply bribery legislation in a more coherent fashion this may become important.

- There continue to be tensions around the use of framework agreements and dynamic purchasing agreements (analogous to indefinite-delivery, indefinite-quantity (IDIQ) contracts in the United States). The restrictions inherent in framework agreements seem likely at last to lead towards an increasing use of dynamic purchasing systems, electronically based systems which allow dynamic substitutions of offered goods and services. See UK Public Contracts Regulations 2015, reg. 34, http://www.legislation.gov.uk/ uksi/2015/102/regulation/34/made.

\section{F. Topics to Watch Going Forward: Performance of Public Sector Contracts Becomes a Political Nightmare}

A number of new twists have been applied to the problems of performance in public sector contracts. Those interested in developing public private partnerships in developing transport service delivery may be interested in the ever growing challenge in holding the operators of train services to the terms of the arrangements that they put forward in their bids. The viability of the 
market is even in question in some important areas of public service delivery. https://www.theguardian.com/business/nils-pratley-on-finance/2018/jan/02/ chris-grayling-east-coast-line-rotten-state-uk-rail-system

The most important and tragic public sector procurement saga arises out of the Grenfell Tower fire last summer. http://www.bbc.com/news/uk-englandlondon-40272168. A number of challenges for the process of specification, award and performance of these contracts will become an increasing focus of attention in the various ongoing inquiries being undertaken in 2018. In short, how could refurbishment of council owned housing to meet environmental standards have led to the tower being turned into a death trap? http://publicsectorblog.practicallaw.com/are-procurement-and-construction-processes-fitfor-purpose/. How is it that whatever is promised in the bid is not delivered in the contract as performed? https://www.architectsjournal.co.uk/news/ fire-safety-review-building-regulations-are-not-fit-for-purpose/10026395. article. These basic, recurring questions will increasingly take centre stage in any review of public sector procurement.

\section{THE UNITED STATES AND INTERNATIONAL PROCURE- MENT $^{4}$}

While Sweden implemented its new procurement law in 2017, and the United Kingdom was largely distracted by Brexit, in the United States procurement reform -- and international procurement relations -- were largely stalled in the first year of the Trump administration. As is discussed below, while the new administration cut back on labor protections (an ironic counterpoint to the Swedish developments noted above), it failed to explain how it would implement the "Buy American" initiative which was touted as a solution for U.S. industry and workers. At the same time, however, legislative reform continued forward in Congress, and while those legislative changes, discussed below, raise new issues for transnational procurement trade, they confirmed some of the more durable aspects of a mature legal regime.

\section{A. Socioeconomic Initiatives in U.S. Procurement}

Unlike Sweden's steady progress, socioeconomic measures were off to a rocky start in the Trump administration. President Trump and Congress summarily ended the Obama administration's "Fair Pay and Safe Workplaces" initiative, which would have barred vendors found guilty of labor violations. See 59 No. 23 GC II 189 (June 21, 2017). Although the "Fair Pay" initiative was hugely unpopular with many in industry, see, e.g., Cameron S. Hamrick \& Robert V. Abbota, The "Fair Pay and Safe Workplaces" Regulations and Guidance Constitute an Unreasonable Use of Federal Authority, 46 Pub. Cont. L.J. 217 (2017), the effort to tie contractor qualification to fair labor standards is a common trend in procurement abroad (see Part II, supra), and abandoning the initiative entirely left questions unanswered as to how, exactly, federal contracting officials should address performance and reputational risks raised by contractors that flout labor standards.

It should also be noted that abandoning the "Fair Pay" initiative did not mean that all labor conditions were stripped from federal procurement. For example, statutory requirements under the Davis-Bacon Act, which dates back to the 1930s, impose "prevailing wage" requirements, and so force contractors to pay workers on federal construction projects wages commensurate with those paid across the relevant region. See, e.g., Paul Greenberg, Daniel Abrahams, Shlomo Katz, Complying with the Davis-Bacon Act, 03-11 Briefing 
Papers 1 (2003). Like the European reforms outlined above, the Davis-Bacon Act's protections were enacted, in important part, to keep low-price contractors from other regions from undercutting local contractors with "imported" low-wage labor. Id. In many ways, the U.S. legal regime has developed in parallel with the expanding European labor protections outlined above -- the U.S. system has simply developed along a different timeline.

\section{B. A Potentially Revamped "Buy American" Initiative}

Although the April 2017 announcement of the Trump administration's much-heralded "Buy American" initiative gave a political boost to European protectionism (see Roland Stein's accompanying analysis), as Jean Heilman Grier noted in her blog the Trump administration did not provide further details on its "Buy American" initiative in 2017, see Jean Heilman Grier, 2018 Government Procurement: Preview of Issues, https://trade.djaghe.com/?cat=4; see also President Trump Signed Buy American Executive Order in April, But Administration Report Remains Incomplete, Targeted News Serv., Dec. 12,2017 , and doubt remained as to whether any new protectionist measures would, in fact, be taken by the administration, see Sen. Baldwin Lambastes Trump on Unfinished, Tardy Buy American Report, Inside U.S. Trade Daily Rep., Dec. 13, 2017, 2017 WLNR 38599103 ("Other industry sources remain skeptical that the report will ever be made public, pointing to a crop of similar reports called for by Trump via executive orders in the spring. ... 'At the end of the day, this [report] could just fall into the heaping pile of presidential promises that end up being incomplete,' the source told Inside U.S. Trade.").

In a news report published early in January 2018, Reuters suggested that the Trump administration's "Buy American" initiative might be turned to increase arms exports by loosening export control requirements. See Mike Stone \& Matt Spetalnick, Exclusive -- Trump to Call on Pentagon, Diplomates to Play Bigger Arms Sales Role -- Sources, Reuters News, Jan. 8, 2018. For the United States' trading partners, this would convert Trump's"Buy American" iniative into a sort of "Buy American Weapons" initiative. but it would not at its heart be a procurement reform. Although the Foreign Military Sales (FMS) program (a likely vehicle for such an initiative) leaves it to the U.S. Department of Defense to use traditional procurement processes to purchase weapons on behalf of foreign customers, see Allen B. Green, International Government Contract Law, ch. 3 (available on Westlaw), published reports indicate that the core elements of the proposed "Buy American" initiative in weapons -- loosened export controls, and more aggressive assistance in foreign military sales by U.S. military and diplomatic personnel abroad -- are only tangentially related to procurement.

Ironically, though, enhanced efforts by the U.S. government to ease export controls and otherwise facilitate U.S. weapons manufacturers' foreign sales relate directly back to the arguments raised by European protectionists in favor of a "European preference" in defense procurement (discussed in Roland Stein's accompanying piece) -- that U.S. military sales are bureaucratic and slow, hampered by unworkable U.S. export controls. If the Trump administration does channel its "Buy American" efforts into weapons sales in this way, it will be coming full circle, to confront the same European protectionists that have been incited by the Trump administration's own protectionist rhetoric.

\section{U.S. Legislative and Regulatory Reforms}

As Steven Schooner and David Berteau note in their accompanying piece, U.S. regulatory reform essentially ground to a halt in the first year

Int'l-2-12 
of the Trump administration, stalled largely by agencies' concerns over the President's new "two-for-one" regulatory bar in fiscal year 2017, which under Executive Order 13771 (Jan. 2017) requires that the costs of every new regulation be offset by elimination of two older regulations. https://www. whitehouse.gov/presidential-actions/presidential-executive-order-reducingregulation-controlling-regulatory-costs/. As a result, only a small handful of new federal procurement regulations were issued in 2017. See, e.g., Defense Procurement \& Acquisition Policy, U.S. Defense Department, FAR Cases Closed As of FY2017, https://www.acq.osd.mil/dpap/dars/closedcases/far.pdf.

That did not mean, however, that all procurement reform ceased, as the alternative channel for reform -- legislative action -- remained open. Title VIII of the National Defense Authorization Act, the perennial legislative vehicle for procurement reform, once again included scores of reform provisions, several of which are of special interest for the international procurement community. See National Defense Authorization Act for FY2018, Pub. L. No. 115-91, title VIII (became law Dec. 12, 2017), available at www.congress.gov.

Two of the NDAA provisions are notable because they show a mature system rocking to one side with stakeholder pressure, then righting itself and so seeming to confirm bedrock best practices:

- Bid Challenges Reconfirmed: In Section 827 of the NDAA, in response to vigorous government stakeholders' criticism of a perceived wave of disruptive bid protests (bid challenges) -- some officials had even called privately for abolishing bid protests entirely -- Congress launched a pilot "loser pays" program, to assess whether large defense contractors, if they lose a bid protest brought at the Government Accountability Office, should be forced to pay the Defense Department's costs in defending the bid protest. This provision may have marked a high-water mark for those opposed to bid protests, however, for only a few days after the NDAA became law, the RAND Corporation delivered a congressionally mandated report (discussed in Steven Schooner and David Berteau's accompanying piece) which concluded that bid protests of defense awards are a rare and healthy part of a procurement system. See Mark V. Arena et al., Assessing Bid Protests of U.S. Department of Defense Procurements: Identifying Issues, Trends, and Drivers (RAND, Dec. 21, 2017), https://www.rand.org/pubs/research_reports/RR2356.html. Putting to one side the obvious problems of eliminating bid challenges (they are called for under most free trade agreements which address procurement, and are enshrined in Article 9 of the UN Convention Against Corruption, which has been signed by almost all nations of the world including the United States), the RAND Corporation report's strong and supportive conclusions suggested that bid challenges will remain a stable part of the U.S. system -- and will continue to expand as a best practice in other jurisdictions.

- Best Value Validated: The RAND report on bid protests, supra, confirmed, at page 19, what many had long argued: that federal contracting officials often resort to price-based awards (typically using the lowest-price, technically acceptable (LPTA) approach) in order to avoid the risk of bid challenges. By basing awards on price alone (the thinking goes), and not balancing quality in a more subjective best-value trade-off, the risk of a bid protest is reduced -- but the user ultimately may not receive the best technical solution. Industry has long criticized LPTA procurement, and in Section 822 of the NDAA for FY2018, Congress reinforced the procedural obstacles to misuse of the LPTA procurement method. This counterpressure to low-priced procure-

Int'l-2-13 
ment seems to confirm a trend worldwide (which has been recognized, for example, in the European Union's and the World Bank's embrace of best-value procurement, when quality matters): procurement systems consistently appear to be evolving away from low-priced procurement methods, and towards more nuanced methods (such as competitive negotiations, or "competitive dialogue" in the European Union) which allow for better trade-offs between price and quality.

\section{Key U.S. Legislative Initiative: Electronic Commerce Plat- forms}

The NDAA for FY2018 also included, in Section 846, a provision which could have serious consequences for international trade in procurement: a pilot program in electronic commerce, which could (in time) allow agencies to make certain purchases directly from commercial online portals.

While this reform seems simple, it could have revolutionary consequences. In a stroke, it could divorce public purchases from public contracts. Unlike current government electronic commerce platforms (such as www.gsaadvantage.gov), which typically rest on standing IDIQ or "framework" agreements, goods and services offered under this pilot program could in principle be purchased directly from vendors, without going through a public contract. This would largely bypass normal contractor qualification and competition requirements, and would make prior notice of opportunities and post hoc publication of awards -- mainstays of transparency -- a thing of the past. As David Drabkin, a commissioner on the Section 809 panel (discussed in the accompanying piece by Steven Schooner and David Berteau), has noted in an informal initial review, this could raise issues under trade agreements such as the Government Procurement Agreement (GPA). The GPA, for example, assumes that covered procurement opportunities and awards will be published, that procurement awards will be competed in a transparent manner, and that contractor qualification will be done in accordance with ordered, established public norms. Thus, beyond being highly disruptive to traditional domestic procurement, this initiative -- informally dubbed by some the "Amazon.gov" initiative -- could radically revamp international procurement obligations, as well.

\section{v. CONCLUSION}

As the discussion above reflects, progress over the past year in public procurement in the three countries highlighted -- Sweden, the United Kingdom, and the United States -- is more notably similar than different. In both Sweden and the United States, for example, there has been extensive discussion of using public procurement to accomplish social and economic goals, whether to protect workers (Sweden) or to encourage domestic manufacturing (the United States). All three countries reflect parallel efforts to address common problems, such as competition, corruption and contract administration. Finally, in all three countries, international and regional trade agreements (such as the WTO Government Procurement Agreement) play important, but probably not dispositive, roles in framing legal reform. Taken together, these developments suggest that while convergence between national procurement regimes is accelerating, that convergence will occur not by force of agreement, but by consensus -- in other words, procurement systems will take common approaches not because they must, but because those common approaches reflect internationally recognized best practices. That, in turn, makes it even more important that transnational discussions of best practices in procure- 
ment grow more robust, and more readily accessible to policymakers and practitioners around the world.

1 As noted, this part of the paper was prepared by Professor Andrea Sundstrand.

2 As noted, this part was prepared by Michael Bowsher QC.

3 A free international forum on bid challenges will be held on the afternoon of March 5, 2018, at King's College, London (KCL). Building on a series of programs between KCL and the George Washington University (GWU) Law School, this conference at Somerset House, London will be the first true transatlantic meeting of judges, officials and senior members of the bar from both Europe and the United States, gathered to address common issues posed by challenges to public contract awards. Further information is available on the KCL and GWU Law School websites.

4 This part was, as noted, prepared by Professor Yukins. 